\title{
'n Vergelyking tussen die kardiostres-indekse van 'n aktiewe en 'n sedentêre populasie
}

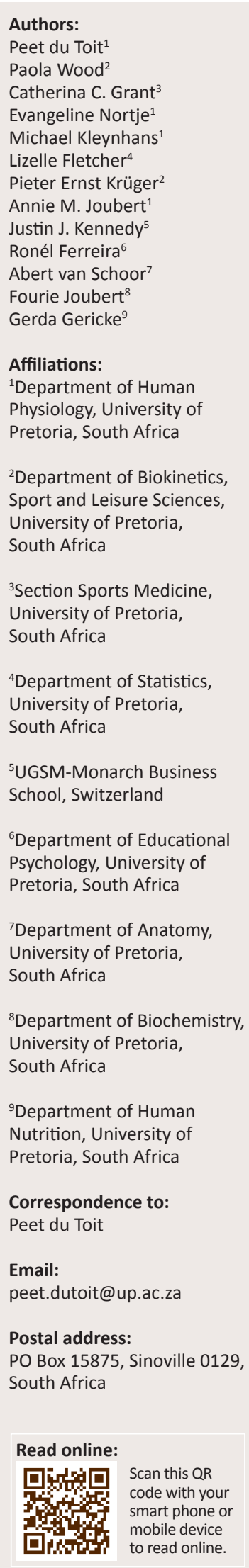

Die moderne leefwyse bring dikwels mee dat ons die belangrikheid van liggaamlike oefening uit die oog verloor. Ons toenemend passiewe leefwyse het gelei tot ' $n$ aansienlike toename in die voorkoms van lewenstylsiektes soos hipertensie en verskeie vorme van vaskulêre patologie. In hierdie studie word die kardiostres-indekse (KSI'e) van aktiewe en sedentêre individue met mekaar vergelyk ten einde insig te verkry in die uitwerking van die aansienlike veranderinge wat in die gemoderniseerde samelewing plaasgevind het. Die aktiewe populasie het bestaan uit 217 weermagrekrute wat reeds 20 weke van hul basiese weermagopleiding voltooi het. Die $(n=126)$ lede van die sedentêre populasie is gewerf uit' $n$ tradisionele tersiêre onderwysinstansie. Die deelnemers uit beide populasies moes drie toetssessies bywoon wat gedurende week 1, week 12 en week 20 gehou is. Hulle het 'n nie-ingrypende Viport ${ }^{\mathrm{TM}}$ toets ondergaan om hul KSI, harttempo en QRS-duur te bepaal. Die resultate het getoon dat alhoewel die basislyn vir KSI, bloeddruk en harttempo aanvanklik hoër was onder die aktiewe populasie, die aanvang van die liggaamsoefeningprogram ten opsigte van hierdie drie faktore 'n geleidelike afname en dus 'n verandering in die rigting, en uiteindelik gesonder marges tot gevolg gehad het. Die KSI het egter nie die normale reikwydte ten opsigte van een van die twee groepe bereik nie, wat daarop gedui het dat alhoewel liggaamlike aktiwiteit fisiologiese stresvlakke verminder, ander sleutelfaktore, te wete leefwyse en stresvlakke, ook in ag geneem moet word. Die studie onderskryf die idee dat 'n toename in liggaamlike aktiwiteit die potensiaal het om 'n individu se vatbaarheid vir kardiovaskulêre siektes te verminder. Die studie ondersoek ook die uitwerking van oefening op die hart deur die gebruik van KSI as 'n meetinstrument.

A comparison between the cardio-stress indices of an active and a sedentary population. Our modern lifestyle often results in the importance of physical exercise being overlooked. The increasingly passive way of life has resulted in a notable increase in the prevalence of lifestyle disorders, such as hypertension and some forms of vascular pathology. This study compares the cardio-stress indices (CSIs) of active and sedentary individuals to provide insight into the impact of the significant changes that have taken place in the modernised society. The active population consisted of 217 military recruits who had completed 20 weeks of basic military training. The sedentary population $(n=126)$ was sourced from a traditional tertiary institution where the focus is on attending lectures. Participants from both populations were required to attend three testing sessions, which were held during Week 1, Week 12 and Week 20. Subjects underwent a non-invasive Viport ${ }^{\mathrm{TM}}$ test to measure their CSI, heart rate and QRS duration. The results showed that although baseline readings for CSI, blood pressure (BP) and heart rate (HR) were initially higher among the active population, the commencement of the physical training programme resulted in a steady decline in respect of these three factors to approach healthier margins. However, the CSI for neither population reached the normal range, indicating that although physical activity reduces physiological stress levels, other key factors, namely lifestyle stress levels, must also be taken into account.The study supports the notion that increased physical activity has the potential to reduce the predisposition of an individual to cardiovascular disorders and contributes towards establishing the effect of training on heart health by using CSI as a means of measurement.

\section{Inleiding}

Ons moderne leefwyse plaas 'n groot hoeveelheid onnodige stres op die liggaam. Dergelike stres kan óf fisiologies, óf sielkundig van aard wees, en beide het ' $n$ negatiewe uitwerking op morbiditeit (sieklikheid ) en mortaliteit (die sterftesyfer). Die toenemend passiewe leefwyse wat

Dates: Received: 19 Aug. 2013 | Accepted: 19 Sept. 2013 | Published: 02 Dec. 2013

How to cite this article: Du Toit, P., Wood, P., Grant, C.C., Nortje, E., Kleynhans, M., Fletcher, L. et al., 2013, "n Vergelyking tussen die kardiostres-indekse van 'n aktiewe en 'n sedentêre populasie', Suid-Afrikaanse Tydskrif vir Natuurwetenskap en Tegnologie 32(1), Art. \#769, 7 pages. http://dx.doi.org/10.4102/satnt.v32i1.769

Copyright: (C) 2013. The Authors. Licensee: AOSIS OpenJournals. This work is licensed under the Creative Commons Attribution License. 
kenmerkend geword het van die tyd waarin ons leef, het 'n merkbare toename in die voorkoms van lewenstylsiektes soos hipertensie (hoë bloeddruk), Tipe 2 diabetes (hoë bloedglukose as gevolg van insulienweerstandigheid), aterosklerose (vetneerlegging op arteriële wande) en vaskulêre patologie tot gevolg (De Vriendt, Moreno \& De Henauw 2009; Sharkey \& Gaskill 2013). Wanneer dit met ander lewenstylsiektes vergelyk word, blyk dit dat kardiovaskulêre siekte (KVS), veral koronêre-arteriesiekte (KAS), die hoogste morbiditeitskoers toon (Sharkey \& Gaskill 2013; De Vriendt et al. 2009). Dit is die gevolg van die vrystelling van epinefrien en norepinefrien in stresbelaaide situasies wat die bloeddruk laat toeneem, die harttempo laat versnel en vasokonstriksie (vaatvernouing) veroorsaak, wat tot verminderde bloedvloei lei en die gevaar van 'n moontlike hartaanval verhoog (Sharkey \& Gaskill 2013). Dit is moontlik dat KVS en ander lewenstylsiektes, soos Tipe 2 diabetes mellitus en hipertensie, sommige komorbiditeitsfaktore gemeen het (Sharkey \& Gaskill 2013; De Vriendt et al. 2009). Hipertensie, wat een van die belangrikste risikofaktore vir KAS is, is ' $n$ toestand wat as ernstig beskou moet word, aangesien dit oor die algemeen asimptomaties bly totdat aansienlike patologiese skade reeds voorgekom en die gevaar van toestande soos ' $n$ hartaanval eksponensieel verhoog het (Sharkey \& Gaskill 2013; Mancia 2013). Chroniese stres as gevolg van lewenstylsiektes tas kardiovaskulêre gesondheid en ander fisiologiese stelsels aan en veroorsaak 'n algehele toename in die patofisiologiese simptome van dergelike siektes (Charmandari, Tsigos \& Chrousos 2005). Langdurige blootstelling aan stres en die hormone wat as gevolg daarvan vrygestel word, byvoorbeeld epinefrien, onderdruk die immuunstelsel (Sharkey \& Gaskill 2013). Dit is die gevolg van die oorstimulering van die adrenale medulla-as en 'n algehele toestand van dishomeostase binne die liggaam (Charmandari et al. 2005; Hamer, Molloy \& Stamatakis 2008). Ons word daagliks gekonfronteer deur gebeure wat stres veroorsaak en wat nie altyd fisiologies van aard is nie (Pollard 1997). Aangesien emosionele stres subjektief beskou word en hoofsaaklik deur 'n individu se eie beskouing van 'n situasie bepaal word, is dit feitlik onmoontlik om 'n stressor wat nie objektief gekwantifiseer kan word nie heeltemal te vermy (Pumprla et al. 2002). Dergelike stressors sal nogtans die hart affekteer; dus is die hart se vermoë om stres te hanteer uiters belangrik in die geval van situasies wat as emosioneel spanningsvol beskou word (Dishman et al. 2000; Phillips et al. 2011; Pumprla et al. 2002; Roemmich et al. 2011). Baie van die belangrikste hedendaagse oorsake van mortaliteit en morbiditeit kan voorkom word indien hulle korrek bestuur of betyds behandel word (Sharkey \& Gaskill 2013; Vuori 2004). KAS kan vererger word, byvoorbeeld indien die hart aan onnodige emosionele stres blootgestel word, wat die waarskynlikheid van voorkombare morbiditeit sal verhoog (Pagani, Lombardi \& Guzzetti 1986; Sharkey \& Gaskill 2013).

\section{Agtergrond}

Onlangs was daar 'n toename in die gewildheid van liggaamsoefening as 'n voorsorgmaatreël om siektetoestande, veral hipertensie en KVS, te voorkom (Cornelissen et al. 2010).
Wanneer 'n mens die vroeëre en hedendaagse definisies van gesondheid met mekaar vergelyk, blyk die gewildheid van voorkomende maatreëls duidelik. Volgens Sharkey en Gaskill (2013) is gesondheid vroeër omskryf as die afwesigheid van siekte. Daarteenoor word gesondheid vandag omskryf as 'n toestand van volslae liggaamlike, geestelike en emosionele welstand, en nie slegs die afwesigheid van siekte of swakheid nie. Die tweede definisie bevestig dat 'n moderne leefwyse vereis dat talle besluite in verband met fisiologiese en psigologiese aspekte geneem moet word ten einde algemene gesondheid te verseker. Liggaamsoefening bied talle lewenstyl- en siekteverwante voordele. Dit blyk dat hoë bloeddruk, die konsentrasies serumtrigliseried en laedigtheid-lipoproteïen-cholesterol, die gevaar van beroerte of voortdurende iskemiese aanvalle (VIA'e) en van kanker (bv. prostaat- en borskanker) verminder kan word deur gereelde oefeninge wat die klem op uithouvermoë plaas (Sharkey \& Gaskill 2013). Daar is ook bevind dat gereelde oefeninge wat uithouvermoë bevorder, die konsentrasie hoëdigtheid-lipoproteïen-cholesterol, insuliensensitiwiteit en die doeltreffendheid van die immuunstelsel verhoog (Sharkey \& Gaskill 2013), en dat daar 'n verband bestaan tussen miokardiale suurstofverbruik en harttempo (HT), bloeddruk (BD) en rustende polsslag (Aghamohamadi et al. 2010). Uiters mededingende, uitputtende of gevaarlike oefening kan die hart egter oorlaai, wat negatiewe gevolge het (Sharkey \& Gaskill 2013; Dishman et al. 2000). Soos reeds vroeër genoem, is dit dus baie belangrik om die hart se vermoë te verhoog om dergelike stres doeltreffend te hanteer ten einde die negatiewe effekte te verminder (Dishman et al. 2000; Pumprla et al. 2002; Sharkey \& Gaskill 2013). Meer oefening en ' $n$ doeltreffender kardiovaskulêre stelsel bring mee dat die stelsel aan minder stres blootgestel word sodat minder epinefrien en kortisol vrygestel en die voordele van oefening en liggaamlike aktiwiteit verhoog word (Cornelissen et al. 2010; Pagani et al. 1986; Sharkey \& Gaskill 2013).

Die kardiostres-indeks (KSI) word gebruik om te bepaal hoe doeltreffend die kardiovaskulêre stelsel die stres kan hanteer waaraan dit blootgestel word (Phillips et al. 2011; Serry 2011). Die KSI bestaan uit twee faktore, te wete veerkrag en kwesbaarheid. Veerkrag word gesien wanneer 'n potensieel spanningsvolle ervaring of stressor korrek bestuur of geslaagd aangepas word tot voordeel van die stelsel (Phillips et al. 2011; Roemmich et al. 2011; Beachle \& Earle 2008). Kwesbaarheid kom voor wanneer 'n stressor nie doeltreffend aangepas of bestuur word nie en gevolglik 'n negatiewe resultaat het (Phillips et al. 2011; Serry 2011). Die KSI word uitgedruk as 'n persentasie (\%), met waardes wat van $0 \%-20 \%$ tot $50 \%$ $100 \%$ wissel. Waardes van $0 \%-20 \%$ word as normaal, en dié van $50 \%-100 \%$ as uiters verhoog geklassifiseer (Energy-lab Technologies 2005). Die Viport ${ }^{\mathrm{TM}}$ word gebruik om die hart en stres te gradeer en bied die moontlikheid van 'n vinnige en doeltreffende EKG-gebaseerde assessering van huidige hartgesondheid. Dit bepaal verskillende waardes, onder andere die KSI (Energy-lab Technologies 2005). Die Viport ${ }^{\mathrm{TM}}$ bepaal ook die harttempo-variasie (HTV), in millisekondes (ms) gemeet, hartritme (ritmies en aritmies), HT in slae per minuut en die QRS-golfduur in ms (depolarisasie van die 
ventrikels van die hart). Die KSI word deur die herleiding van HTV, QRS-duur en HT bepaal, en die hartklopritme deur die gebruik van bepaalde algoritmes (Aghamohamadi et al. 2010; Energy-lab Technologies 2005). HTV word bepaal deur die standaardafwyking van lesings van die R-R-interval (SDRR), wat met die tydsverskil (in ms gemeet) tussen twee R-pieke in twee opeenvolgende hartklopsiklusse ooreenstem (Chen et al. 2007; Malik 1996; Spiegelhalder et al. 2011; Woo et al. 1994). Wanneer HTV- en KSI-waardes vergelyk word, dui 'n hoë HTV op normale KSI-waardes, aangesien die kardiovaskulêre stelsel aanpas en die stres doeltreffender hanteer (Energy-lab Technologies 2005).

Die outonome senustelsel, OSS, bestaan uit die simpatiese senustelsel, SSS, en die parasimpatiese senustelsel, PSS, en sorg vir die handhawing van homeostase (Beachle \& Earle 2008; Saladin 2007). Die OSS-waardes verskaf ook 'n aanduiding van die betroubaarheid van die korrelasie tussen die twee substelsels (Buttagat et al. 2011; Chen et al. 2007; Energy-lab Technologies 2005; Lewis et al. 2007). Dit blyk dat die invloed van die simpatiese senustelsel (SSS) en die parasimpatiese senustelsel (PSS) op BD deur frekwensie bepaal word (Buttagat et al. 2011; Malik 1996). Die SSS is doeltreffend wanneer die liggaam blootgestel word aan 'n stressor wat homeostase ontwrig; dus bevorder die SSS ook die herstel van homeostase (Beachle \& Earle 2008; Saladin 2007). Die PSS bevorder die handhawing van rustende homeostase (Beachle \& Earle 2008; Saladin 2007). Totale HTV is ' $n$ aanduider van die werking van die outonome senustelsel (OSS) en die wyse waarop dit liggaamstressors hanteer. Vorige navorsing het getoon dat aktiwiteitsvlakke beduidende fluktuasies in die HTV-lesings van populasies kan veroorsaak (Spiegelhalder et al. 2011; Woo et al. 1994). Die HTV-lesings van gesonde individue is oor die algemeen hoër, aangesien die waarde ' $n$ aanduiding verskaf van hoe geredelik die hart kan verander ten einde by sy omgewing aan te pas en homeostase in die liggaam in stand te hou (Malik 1996). Soos vroeër genoem, word hoë HTV-waardes aan normale KSI-waardes gekoppel (Energy-lab Technologies 2005). 'n Laer HTV word gewoonlik as 'n risikofaktor vir KVS beskou (Energy-lab Technologies 2005). HTV verskaf egter nie ' $n$ onweerlegbare diagnose van hartsiektes nie, aangesien daar ook ander patologieë is wat 'n laer HTV tot gevolg kan hê (Chen et al. 2007).

Volgens vroeëre inligting kan die algehele bydrae van die aktiwiteitsvlakke op die KSI bepaal word deur aktiewe en sedentêre populasies, met verskillende vlakke van aktiwiteit, met mekaar te vergelyk. Benewens KSI behoort ander faktore soos HTV, BD en rustende HT ook in ag geneem te word wanneer die bydrae van aktiwiteitsvlak tot liggaamstressors wat uit lewenstylkeuses voortspruit, bepaal word. Met hierdie navorsingsprojek beoog ons om te bewys dat ' $n$ aktiewe leefwyse met gereelde oefeninge wat uithouvermoë bevorder ' $n$ positiewe uitwerking op die KSI sal hê, met 'n gepaardgaande daling in BD en HT. Dit sal uiteindelik 'n hoë HTV-waarde tot gevolg hê, wat 'n groter mate van aanpassing by stres en die handhawing daarvan sal weerspieël. Die resultate van die navorsing sal insig bied in die impak van die gemoderniseerde samelewing op leefwyse en algehele gesondheid.

\section{Metodes \\ Deelnemers}

Die 343 deelnemers het bestaan uit mans en vrouens van tussen 18 en 26 jaar. 'n Kontrole-studieontwerp is gebruik, aangesien die navorsers vanuit die staanspoor geweet het dat die 217 weermagrekrute reeds 20 weke basiese militêre opleiding ondergaan het, terwyl die sedentêre populasie $(n=126)$ by ' $n$ tradisionele onderwysinstelling gewerf is waar die fokus op die bywoning van lesings is. Die prosedures is aan al die deelnemers verduidelik en hulle het tot deelname ingestem. Deelnemers uit beide populasies moes drie toetssessies bywoon wat in week 1 , week 12 en week 20 gehou is. Die eerste week waartydens die weermagpopulasie getoets is, het met die aanvang van die eerste week van hul basiese opleiding saamgeval. Die eerste week waartydens die sedentêre populasie getoets is, was die tweede week in Februarie, wat die begin van die akademiese jaar was. Al die deelnemers het 'n lewenstyl-, bloeddruk- en kardiostresassessering ondergaan om die beskikbaarheid van 'n algehele lewenstylevaluasie vir elke lid van albei groepe te verseker.

\section{Bloeddrukassessering}

Die deelnemers het bly sit terwyl hulle sistoliese en diastoliese BD by Korotkoff-klanke I en IV met behulp van 'n kwiksilwer-sfigmomanometer beluister is. Die lesings is in millimeter kwiksilwer $(\mathrm{mmHg})$ as sistolies of diastolies opgeteken.

\section{Kardiostresindeks-assessering}

Die KSI is geassesseer met behulp van 'n Viport ${ }^{\mathrm{TM}}$, 'n hart- en stresondersoekinstrument wat ' $n$ vinnige EKG-gebaseerde assessering van huidige hartgesondheid moontlik maak. Deur hierdie instrument te gebruik kan verskeie HTV-parameters deur middel van algoritmes na die KSI oorgedra word. KSI, hartritme, rustende BD en QRS-duur in millisekondes (ms) is gemeet. Die deelnemers het voor die toetsing gesit en was ontspanne. Die drie metaalhoekies (elektrodes) van die Viport $^{\mathrm{TM}}$ is met 'n geleidingsjel benat, waarna die toestel op die linkerkant van die deelnemers se bors geplaas is terwyl daar seker gemaak is dat al drie elektrodes wel kontak gemaak het met hul vel. Die korrekte posisie vir die meting is geïdentifiseer deur die voorvinger op die deelnemer se linkersleutelbeen te plaas voordat die Viport ${ }^{\mathrm{TM}}$ ongeveer drie vingerwydtes onder dié posisie vasgeheg is. Nadat die Viport ${ }^{\mathrm{TM}}$ korrek geplaas is, het die meting begin. Deelnemers is versoek om rustig asem te haal en nie tydens die toets, wat twee minute geduur het, te beweeg of te praat nie. Die hoorbare sein aan die einde van elke meting het aangedui dat dit tyd was om die Viport ${ }^{\mathrm{TM}}$ vanaf die deelnemer se bors te verwyder en die resultaat wat op die skerm vertoon is aan te teken. 'n KSI-lesing van $20 \%-25 \%$ of minder dui op 'n hoë HTV, dit wil sê 'n normale hartstreslas. Die normale HT vir ' $n$ volwassene behoort tussen 60 en 80 slae per minuut 
te wees, en die QRS-duur tussen 60 en 110 ms (Energy-lab Technologies 2005). 'n Ritmiese of aritmiese hartklop word met ' $n$ 'Ja' of ' $n$ 'Nee' op die skerm aangedui, en 'n afwyking met R-R-intervallesings (SDRR) dui op'n standaardafwyking as 'n absolute graad van HTV in ms.

\section{Basiese weermagopleiding}

Die weermagrekrute het die basiese standaardprogram vir weermagopleiding oor ' $\mathrm{n}$ tydperk van 20 weke voltooi. Dié program, gebaseer op die American College of Sports Medicine's Guidelines for Exercise Testing and Prescription, het bestaan uit strawwe oefeninge van meer as ses metaboliese ekwivalente (MET'e) waaraan die rekrute twee uur daagliks deelgeneem het vir die duur van die 20 weke waartydens die studie onderneem is (Thompson, Gordon \& Pescatello 2010; Wood, Krüger \& Grant 2010). Tydens die opleidingstydperk was daar 48 liggaamsoefeningsessies van 40 min elk. Tabel 1 bevat 'n opsomming van die tyd wat aan elke liggaamsoefeningkomponent toegewys is (Wood et al. 2010).

\section{Data-ontleding}

Data is na weke 1, 12 en 20 vertroulik aangeteken. Herhalingsmetings (repeated measures) MANOVA (Multivariate Ontledingsvariansie) is gebruik om die resultate statisties te ontleed ten einde teen 'n oordrewe Tipe 1-fout te waak. Post hoc-ontledings het bestaan uit pare $t$-toetse wat gedoen is om die data in pare te vergelyk. Data vir weke 1, 12 en 20 is binne die populasies vergelyk om vas te stel of die liggaamlike aktiwiteitsvlakke 'n verbetering of 'n verswakking tot gevolg gehad het.

\section{Resultate}

'n Vergelyking van die KSI-lesings vir die basislyn (week 1) het geen noemenswaardige verskil tussen die twee groepe aangedui nie. Die resultate vir weke 12 en 20 het egter statisties beduidende verskille in die KSI-waardes van deelnemers uit die onderskeie populasies getoon. Die sistoliese en diastoliese BD-lesings, asook die BD tussen groepe, het 'n beduidende verskil ( $p=0.001)$ tussen die twee proefpopulasies getoon.

Die vergelyking van KSI-resultate binne-in die groep in Tabel 2 toon duidelik ' $n$ aansienlike afname in die gemiddelde KSIpersentasie van die aktiewe populasie vanaf week 1 tot week 20 , terwyl daar gedurende dieselfde tydperk 'n beduidende toename in die sedentêre bevolking se KSI was. Tabel 3 toon dat ooreenstemmende resultate verstaan kon word toe die gemiddelde HT van die twee populasies vergelyk is, met 'n beduidende daling in die aktiewe populasie se gemiddelde HT en 'n geringe toename in dié van die sedentêre populasie.

Wanneer sistolies BD vergelyk word (Tabel 4), sien ons 'n geleidelike daling in die resultate van die aktiewe populasie vanaf week 1 tot week 2, terwyl dié vir die sedentêre populasie gedurende week 12 'n hoogtepunt bereik het. Sistoliese BD (Tabel 4) het beduidend gedaal in die aktiewe populasie vanaf weke 1 tot 20. Diastoliese BD (Tabel 5) het in albei populasies ' $n$ daling getoon, maar in 'n groter mate in die aktiewe populasie.

\section{Bespreking}

Die KSI, HT en sistoliese BD vir die sedentêre populasie is effens laer, maar in die eerste week was die diastoliese lesings hoër. Selfs al was die KSI laer, is dit nogtans as ietwat hoog beskou, aangesien dit bo die optimale variasie $(0 \%-$ $20 \%$ ) was. Nie een van die twee groepe het egter tekens van 'n vorige teenwoordigheid van kardiovaskulêre patologie getoon nie, soos blyk uit die QRS-duur, wat binne die korrekte variasie is.

Data wat gedurende week 12 ingesamel is, toon ' $n$ beduidende daling in die KSI en BD van die aktiewe populasie. Dit impliseer ' $n$ daling in hierdie lesings na die aanvang van intervensie deur middel van die liggaamsoefeningprogram. 'n Sterk afname in die KSI-waardes van die aktiewe populasie gedurende weke 1 tot 12 , gevolg deur 'n afplatting in die afname (weke 12 tot 20) is opgemerk. Dit dui daarop dat alhoewel 'n aktiewe leefwyse aanvanklik 'n aansienlike afname in KSI getoon het, dit moontlik nie die enigste bydraende faktor was nie. Die sedentêre populasie se KSI het regdeur die proefperiode van 20 weke 'n geleidelike toename getoon, met die grootste verskil tussen week 1 en week 12 . Dit kan toegeskryf word aan die verskillende toenemende stressors waaraan die studente blootgestel is namate die eksamens aan die einde van die semester nadergekom het. In die geheel dui die KSI-resultate op 'n daling in KSI-lesings namate fiksheidsvlakke verhoog het. Hierdie korrelasie word deur die kardiovaskulêre fiksheidresultate van die twee populasies onderskryf. $\mathrm{VO}_{2} \max$ is gebruik as 'n maatstaf vir fiksheid en het 'n sterk korrelasie met die KSI-resultate getoon. Toe fiksheidsvlakke gedurende week 1 vergelyk is, het dit geblyk dat die sedentêre populasie se kardiovaskulêre fiksheid hoër as dié van die intervensiegroep was. Die $\mathrm{VO}_{2}$ max van die aktiewe populasie het egter gedurende die eerste 12 weke van die opleidingsprogram toegeneem en was uiteindelik heelwat hoër as dié van die kontrolegroep.

Wat die rustende HT betref, is bevind dat alhoewel die gemiddelde HT van die sedentêre populasie aanvanklik laer as dié van die aktiewe populasie was, daar met die aanvang van die semester 'n geringe toename in die algehele HT van die sedentêre populasie was. Dié toename kan moontlik dui op 'n groter mate van fisiologiese stres, aangesien dit bekend is dat die SSS gedurende tye wanneer stresvlakke toeneem, geaktiveer word en die HT sal laat toeneem. Die hoë fisiologiese stressors wat in die loop van die semester voorkom, kan toegeskryf word aan die toenemende werklas en die naderende eksamens.

Gedurende die basislynassessering was sowel die diastoliese as die sistoliese BD van albei groepe binne die normale grense. Die sedentêre populasie se BD het gedurende die hele tydperk 
TABEL 1: Tyd wat tydens die basiese weermagopleiding aan die liggaamsoefeningprogram gewy is.

\begin{tabular}{lll}
\hline LO-programkomponent & Weerstand & $\begin{array}{l}\text { Tyd (minute) gedurende } \\
\text { opleidingstydperk toegewys }\end{array}$ \\
\hline Opwarming & Geen & 322 \\
$\begin{array}{l}\text { Oefeninge vir bo-liggaamspiere om uithouvermoë te } \\
\text { verbeter }\end{array}$ & LG & - \\
opleidingstydperk voltooi
\end{tabular}

LG, Liggaamsgewig.

$\dagger$, Vanaf week 1 is drie volledige stelle van 10 tot 12 herhalings van oefeninge vir verskillende spiergroepe in dié deel van die liggaam voltooi; vanaf week 1 tot week 2 is twee stelle van 10 tot 12 herhalings van oefeninge vir dié deel van die liggaam voltooi, waarna hulle in week 3 tot week 4 tot by 10 tot 12 herhalings van drie stelle gevorder het.

$\$$, Vanaf week 5 tot week 12 is al die oefeninge in pare en met houtpale met ' $\mathrm{n}$ gewig van $20 \mathrm{~kg}$ vir die verskillende spiergroepe in dié deel van die liggaam voltooi deur met twee stelle van 10 tot 20 herhalings te begin en tot by drie stelle van 10 tot 20 herhalings te vorder

TABEL 2: Vergelyking van kardiostres-indekse \%-resultate vir weke 1, 12 en 20 (gemiddelde \pm SA).

\begin{tabular}{|c|c|c|c|c|}
\hline Populasie & Week 1 & Week 12 & Week 20 & Vlak van betekenisvolheid \\
\hline \multirow[t]{3}{*}{ Sedentêre populasie ( $n=126$ ) } & $28.4 \pm 21.1$ & $30.3 \pm 20.0$ & $31.04 \pm 23.2$ & w 1 en w12* \\
\hline & - & - & - & w12 en w20* \\
\hline & - & - & - & w1 en w20* \\
\hline \multirow[t]{3}{*}{ Aktiewe populasie $(n=217)$} & $31.9 \pm 21.5$ & $23.7 \dagger \pm 17.1$ & $23.29 \dagger \pm 19.0$ & w1 en w12* \\
\hline & - & - & - & w12 en w20* \\
\hline & - & - & - & w1 en w20* \\
\hline
\end{tabular}

w, week.

$\uparrow$, Beduidende verskil tussen die sedentêre en die aktiewe populasie.

$*, p>0.05$.

TABEL 3: Vergelyking van harttempo-resultate vir weke 1, 12 en 20 (gemiddelde \pm SA).

\begin{tabular}{|c|c|c|c|c|}
\hline Populasie & Week 1 & Week 12 & Week 20 & Vlak van betekenisvolheid \\
\hline \multirow[t]{3}{*}{ Sedentêre populasie $(n=126)$} & $78.2 \pm 13.3$ & $81.6 \pm 12.8$ & $80.7 \pm 14.2$ & w1 en w12* \\
\hline & - & - & - & w12 en w20* \\
\hline & - & - & - & w1 en w20* \\
\hline \multirow[t]{3}{*}{ Aktiewe populasie ( $n=217$ ) } & $83.2 \pm 13.1$ & $74.8 \dagger \pm 11.0$ & $77.4 \dagger \pm 10.5$ & w1 en w12* \\
\hline & - & - & - & w12 en w20* \\
\hline & - & - & - & w1 en w20* \\
\hline
\end{tabular}

w, week.

$\dot{\dagger}$, Beduidende verskil tussen die sedentêre en die aktiewe populasie.

$*, p>0.05$.

TABEL 4: Vergelyking van sistoliese bloeddruk ( $\mathrm{mmHg}$ )-resultate vir weke 1, 12 en 20 (gemiddeld $\pm \mathrm{SA}$ ).

\begin{tabular}{|c|c|c|c|c|}
\hline Populasie & Week 1 & Week 12 & Week 20 & Vlak van betekenisvolheid \\
\hline \multirow[t]{3}{*}{ Sedentêre populasie $(n=126)$} & $124.2 \pm 15.1$ & $128.6 \pm 13.4$ & $121.1 \pm 13.1$ & w 1 en w12* \\
\hline & - & - & - & w12 en w20* \\
\hline & - & - & - & w1 en w20* \\
\hline \multirow[t]{3}{*}{ Aktiewe populasie $(n=217)$} & $126.9 \pm 13.5$ & $126.5 \pm 12.3$ & $115.5 \dagger \pm 10.2$ & w1 en w12* \\
\hline & - & - & - & w12 en w20* \\
\hline & - & - & - & w1 en w20* \\
\hline
\end{tabular}

w, week.

$\dagger$, Beduidende verskil tussen die sedentêre en die aktiewe populasie.

$*, p>0.05$.

TABEL 5: Vergelyking tussen diastoliese bloeddruk ( $\mathrm{mmHg}$ )-resultate vir weke 1, 12 en 20 (gemiddeld $\pm \mathrm{SA}$ ).

\begin{tabular}{lllll}
\hline Populasie & Week 1 & Week 12 & Week 20 & Vlak van betekenisvolheid \\
\hline Sedentêre populasie $(n=126)$ & $80.7 \pm 7.8$ & $84.3 \pm 9.2$ & $78.5 \pm 9.3$ & w1 en w12* \\
w12 en w20* & & w1 en w20* \\
Aktiewe populasie $(n=217)$ & $77 \pm 8.0$ & $74.5 \dagger \pm 7.6$ & $67.8 \dagger \pm 7.5 \quad$ w1 en w12* \\
& & & w12 en w20* en w20* \\
\hline
\end{tabular}

w, week.

$\dagger$, Beduidende verskille tussen die sedentêre en die aktiewe populasie.

$*, p>0.05$. 
van 20 weke betreklik konstant gebly. Daar was 'n geringe toename ten tye van die toetsing in week 12 , wat toegeskryf kan word aan die deelnemers se liggaamsaanpassings by die veranderende stressors gedurende die eksamens. Die aktiewe populasie het ' $n$ daling getoon ten opsigte van beide sistoliese en diastoliese BD en die lesing vir week 20 was gemaklik binne die gewenste variasie. Aangesien hipertensie vroeër as een van die hoofprobleme van lewenstylsiektes geïdentifiseer is, is hierdie bevindinge beduidend.

\section{Sterk punte}

Die Viport $^{\mathrm{TM}}$ en KSI verskaf aan mediese praktisyns 'n ingreepvrye tegniek wat hulle in staat stel om kardiovaskulêre abnormaliteite, asook fisiologiese stres wat kan lei tot siekte te diagnoseer. Dit kan praktisyns moontlik help om die ontwikkeling van KVS in 'n latere stadium in die lewe te voorkom. Dit verskaf ook aan hulle 'n stuk gereedskap wat hulle toelaat om die vordering van behandeling te monitor, selfs al is die behandeling oefeningof farmakologies gebaseerd. Hierdie navorsing illustreer dat oefening heilsaam kan wees by die voorkoming van KVS of behandeling van individue wat aan KVS ly. Fisieke oefening word daarom toenemend belangrik in die daaglike roetines en lewens van individue.

\section{Swakhede}

KSI is sensitief vir slaapkwaliteit, fisieke aktiwiteit, rook en kaffeïen. Alhoewel deelnemers aangeraai is om hierdie dinge voor toetsing te vermy is dit moeilik om alle aspekte te kontroleer.

\section{Gevolgtrekkings}

Die studie het getoon dat daar 'n verband is tussen 'n aktiewe leefwyse, laer KSI en verwante metings. Dit het geblyk dat almal deur daaglikse stres beïnvloed word en dat dit nie heeltemal vermy kan word nie, maar dat matige aktwiteitsvlakke die liggaam kan help om die ontwrigting van homeostase wat daardeur veroorsaak kan word te hanteer. Daar is egter ook baie ander faktore wat gewysig kan word en wat oorweeg behoort te word wanneer 'n poging aangewend word om vatbaarheid vir hierdie siektes te verminder, onder andere dieet, lewenstylgewoontes (rook en alkoholgebruik) en psigologiese stres. Die studie bevestig verslae waarvolgens 'n aktiewe leefwyse help om $\mathrm{BD}$ te verlaag en daardeur bydra tot die voorkoming van hipertensie, wat een van die belangrikste oorsake van morbiditeit in individue met lewenstylsiektes is (Ainsworth \& Pettee 2009; McEwen \& Gianaros 2010).

Ons bevindinge staaf die idee dat liggaamlike aktiwiteit een van die belangrikste intervensies is waardeur die voorkoms van verskeie kardiovaskulêre komplikasies en risiko's verminder kan word (Vuori 2004). Daar bestaan bewyse dat 'n groter mate van liggaamlike aktiwiteit verband hou met vermindering in die voorkoms van mortaliteit en morbiditeit as gevolg van kardiovaskulêre siektes, terwyl daar 'n sterk verwantskap tussen sedentêre leefwyses en verswakte hartgesondheid bestaan (Ainsworth \& Pettee 2009; Sharkey \& Gaskill 2013; Vuori 2004). In 'n internasionaal beheerde gevallestudie oor risikofaktore vir kardiovaskulêre toestande is bevind dat liggaamlike onaktiwiteit een van die belangrikste gedragsvorme is wat tot hartsiekte bydra, met data wat daarop dui dat $12 \%$ van alle hartaanvalle aan 'n gebrek aan liggaamlike aktiwiteit te wyte is (Ainsworth \& Pettee 2009).

Benewens die feit dat liggaamlike aktiwiteit die hart beskerm, bied dit ook voordelige indirekte meganismes vir die vermindering van kardiovaskulêre risiko. Daar is alreeds bewys dat gereelde deelname aan liggaamlike aktiwiteite die verhouding tussen die verstand en die liggaam versterk, wat beter fisiologiese reaksies op psigologiese eise impliseer, byvoorbeeld getemperde bloeddrukreaksies op geestelike stres (McEwen \& Gianaros 2010; Vuori 2004). Moontlike dergelike meganismes kan verhoogde neurogenese en neurotrofienuitpersing in die brein insluit (McEwen \& Gianaros 2010). Studies het ook getoon dat aërobiese oefeninge angstigheid verlig, ontspanning bevorder en spanning verminder, en gevolglik ' $n$ algehele verbetering ten opsigte van subjektiewe welstand teweegbring (Knapen et al. 2008; Vuori 2004).

Mense met 'n aktiewe leefwyse sal dus beter fisiologiese hulpmiddels hê om die talle daaglikse stressors die hoof te kan bied en hul KSI sal laer wees as dié van mense met 'n sedentêre leefwyse. Die studie het ook bewys dat die Viport nuttig kan wees om stresvlakke en die gevolg daarvan op populasies nie-ingrypend te ondersoek.

\section{Erkenning Outeursbydrae}

P.d.T. (Universiteit van Pretoria) was die projekleier en E.N. (Universiteit van Pretoria) was verantwoordelik vir die samestelling van oorspronklike manuskrip. P.E.K. (Universiteit van Pretoria); P.W. (Universiteit van Pretoria); C.G. (Universiteit van Pretoria); P.d.T. en E.N. het die redigering en finale voorbereiding van die manuskrip behartig, waar L.F. (Universiteit van Pretoria) en M.K. (Universiteit van Pretoria) verantwoordelik was vir die statistiese analise. P.W.; C.G.; P.d.T.; E.N. en M.K. was betrokke by die projekontwerp, dataversameling en uitvoering van die toetsprosedures. A.M.J. (Universiteit van Pretoria); J.J.K. (UGSM-Monarch Besigheidsskool); A.v.S. (Universiteit van Pretoria); F.J. (Universiteit van Pretoria); R.F. (Universiteit van Pretoria) en G.G. (Universiteit van Pretoria) het konseptuele bydraes gelewer.

\section{Mededingende belange}

Die outeurs verklaar hiermee dat hulle geen finansiële of persoonlike verbintenis het met enige party wat hulle nadelig of voordelig kon beïnvloed het in die skryf van hierdie artikel nie. 


\section{Literatuurverwysings}

Aghamohamadi, D., Eidy, M., Pourfathi, H., Hoseinzadeh, H., Sharabiani, B.A. \& Golzari, S., 2010, 'Comparison of cardiac stress index with rate pressure product in trans-abdominal prostatectomy', Journal of Cardiovascular and Thoracic Research 2(1), 35-38.

Ainsworth, B.E. \& Pettee, G.K.K., 2009, 'Multiple approaches to reducing the burden of cardiovascular disease: Summary and conclusion', American Journal of Lifestyle Medicine 3 (suppl.1), S69-S72. http://dx.doi.org/10.1177/1559827609337586

Beachle, T.R. \& Earle, R.W., 2008, 'Essentials of strength training and conditioning', 3rd edn., Champaign, IL, Human Kinetics.

Buttagat, V., Eungpinichpong, W., Chatchawan, U. \& Kharmwan, S., 2011, 'The immediate effects of traditional Thai massage on heart rate variability and stressrelated parameters in patients with back pain associated with myofascial trigge points', Journal of Bodywork and Movement Therapies 15(1), 15-23. http:// dx.doi.org/10.1016/j.jbmt.2009.06.005, PMid:21147414

Charmandari, E., Tsigos, C., Chrousos, G., 2005, 'Endocrinology of the stress response', Annual Review of Physiology 67, 259-284. http://dx.doi.org/10.1146/annurev. physiol.67.040403.120816, PMid:15709959

Chen, S.R., Lee, Y.J., Chiu, H.W. \& Jeng, C., 2007, 'Impact of glycemic control, disease duration, and exercise on heart rate variability in children with type 1 diabetes mellitus', Journal of the Formosan Medical Association 106(11), 935-942. http:// dx.doi.org/10.1016/S0929-6646(08)60064-9

Cornelissen, V.A., Verheyden, B., Aubert, A.E. \& Fagard, R.H., 2010, 'Effects of aerobic training intensity on resting, exercise and post-exercise blood pressure, heart rate and heart-rate variability', Journal of Human Hypertension 24(3), 175-182. http:// dx.doi.org/10.1038/jhh.2009.51, PMid:19554028

De Vriendt, T., Moreno, L.A. \& De Henauw, S., 2009, 'Chronic stress and obesity in adolescents: Scientific evidence and methodological issues for epidemiological research', Nutrition, Metabolism and Cardiovascular Diseases 19, 511-519. http://dx.doi.org/10.1016/j.numecd.2009.02.009, PMid:19362453

Dishman, R.K., Nakamura, Y., Garcia, M.E., Thompson, R.W., Dunn, A.L., Blair, S.N., 2000, 'Heart rate variability, trait anxiety, and perceived stress among physically fit men and women', International Journal of Psychophysiology, 37, pp.121-133. http://dx.doi.org/10.1016/\$0167-8760(00)00085-4

Energy-lab Technologies, 2005, Innovative heart and stress screening technologies, pamphlet, Energy-lab Technologies, $\mathrm{GmbH}$.

Hamer, M., Molloy, G.J., Stamatakis, E., 2008, 'Psychological distress as a risk factor for cardiovascular events', Journal of the American College of Cardiology B, 52(25) 2156-2162.

Knapen, J., Sommerijns, E., Vancampfort, D., Sienaert, P., Pieters, G., Haake, P., Probst, M. \& Peuskens, J., 2008, 'State anxiety and subjective well-being responses to acute bouts of aerobic exercise in patients with depressive and anxiety disorders' British Journal of Sports Medicine 43, 756-759. http://dx.doi.org/10.1136/ bjsm.2008.052654

Lewis, M.J., Kingsley, M., Short, A.L. \& Simpson, K., 2007, 'Rate of reduction of heart rate variability during exercise as an index of physical work capacity', Scandinavian Journal of Medicine and Science in Sports 17(6), 696-702. http:// dx.doi.org/10.1111/j.1600-0838.2006.00616.x, PMid:17346290
Malik, M., 1996, 'Heart rate variability: Standards of measurement, physiological interpretation, and clinical use', Circulation 93(5), 1043-1065. http://dx.doi. org/10.1161/01.CIR.93.5.1043

Mancia, G., 2013, 'ESH/ESC Guidelines for the management of arterial hypertension', The European Heart Journal 34(28) 2159-2219. http://dx.doi.org/10.1093/ eurheartj/eht151

McEwen, B.S. \& Gianaros, P.J., 2010, 'Central role of the brain in stress and adaptation: Links to socioeconomic status, health, and disease', Annals of the New York Academy of Sciences 1186, 190-222. http://dx.doi.org/10.1111/j.17496632.2009.05331.x

Pagani, M., Lombardi, F., Guzzetti, S., 1986, 'Power spectral analysis of heart rate and arterial pressure variabilities as a marker of sympatho-vagal interaction in man and conscious dog', Circulation Research 59(2), 178-193. http://dx.doi. man and conscious dog', Circulation Research
org/10.1161/01.RES.59.2.178, PMid:2874900

Phillips, A.C., Der, G., Shipton, D. \& Benzeval, M., 2011, 'Prospective associations between cardiovascular reactions to acute psychological stress and change in physical disability in a large community sample', International Journal of Physchophysiology 81(3), 332-337. http://dx.doi.org/10.1016/j. ijpsycho.2011.08.002, PMid:21855582

Pollard, T.M., 1997, 'Physiological consequences of everyday psychosocial stress', Collegium Antropologicum 21, 17-28. PMid:9225496

Pumprla, J., Howorka, K., Groves, D., Chester, M. \& Nolan, J., 2002, 'Functional assessment of heart rate variability: Physiological basis and practical applications' International Journal of Cardiology 84, 1-14. http://dx.doi.org/10.1016/S01675273(02)00057-8

Roemmich, J.N., Feda, D.M., Seelbinder, A.M., Lambiase, M.J., Kala, G.K. \& Dorn, J., 2011, 'Stress-induced cardiovascular reactivity and atherogenesis in adolescents', Atherosclerosis 215(2), 465-470. http://dx.doi.org/10.1016/j. atherosclerosis.2010.12.030, PMid:21296350, PMCid:PMC3072778

Saladin, K.S., 2007, 'Anatomy and physiology: The unity of form and function', 4th edn., McGraw-Hill , New York. PMCid:PMC2099298

Serry, M.D., 2011, 'Challenge or threat? Cardiovascular indexes of resilience and vulnerability to potential stress in humans', Neuroscience and Behaviour Reviews 35(7), 1603-1610. http://dx.doi.org/10.1016/j.neubiorev.2011.03.003, Reviews 35(7),
PMid:21396399

Shephard, R.J., 2013, 'Fitness and health', in B.S. Sharkey \& S.E. Gaskill, Human Kinetics, 7th edn., Champaign, IL.

Spiegelhalder, K., Fuchs, L., Ladwig, J., Kyle, S.D., Nissen, C., Voderholzer, U., Feige, B. \& Riemann, D., 2011, 'Heart rate and heart rate variability in subjectively reported insomnia', Journal of Sleep Research 20(1pt2), 137-145. http://dx.doi. org/10.1111/j.1365-2869.2010.00863.x, PMid:20626615

Thompson, W.R., Gordon, N.F. \& Pescatello, L.S., 2010, 'Benefits and risks associated with physical activity', in ACSM's Guidelines for Exercise Testing and Prescription, 8th edn., 4, Wolters Kluwer Lippincott Williams \& Wilkins, Philadelphia, USA.

Woo. M.A., Stevenson, T.W.G., Moser, D.K. \& Middlekauff, H.R., 1994, 'Complex heart rate variability and serum norepinephrine levels in patients with advanced heart failure', Journal of the American College of Cardiology 23(3), 565-569. http:// dx.doi.org/10.1016/0735-1097(94)90737-4

Wood, P.S., Krüger, P.E. \& Grant, C.C., 2010, 'DEXA-assessed regional body composition changes in young female military soldiers following 12 weeks of periodised training', Ergonomics 53(4), 537-547. http://dx.doi.org/10.1080/00140130903528160, PMid:20309749

Vuori, I., 2004, Physical inactivity is a cause and physical activity is a remedy for major public health problems, Kinesiology 36(2), 123-153. 